\title{
A comparative study on phyllosilicate and tectosillicate mineral structural properties
}

\author{
Marinos Stylianou ${ }^{1}$; Vassilis Inglezakis²; Grigorios Itskos ${ }^{3}$; Albina Jetybayeva²; Maria Loizidou ${ }^{4}$; \\ Agapios Agapiou ${ }^{5}$
}
${ }^{1}$ University of Cyprus, Department of Civil \& Environmental Engineering, NIREAS-International Water Research Center, Subsurface Research Laboratory, Nicosia, Cyprus
${ }^{2}$ Nazarbayev University, School of Engineering, Chemical Engineering Department, Astana, Republic of Kazakhstan

${ }^{3}$ Purdue University, School of Materials Engineering. West Lafayette, IN 47907, USA

${ }^{4}$ National Technical University of Athens, School of Chemical Engineering, Unit of Environmental Science and Technology (UEST), Athens, Greece

${ }^{5}$ University of Cyprus, Department of Chemistry, P.O. Box 20537, 1678 Nicosia, Cyprus

\begin{abstract}
The present study examines various methods used for the characterization of three common natural silicate minerals, one zeolite (clinoptilolite) and two clays (montmorillonite and vermiculite). Characterization of natural minerals were performed through a series of analytical measurements so as gather all the information needed regarding their properties, in order to distinguish them from "similar" minerals such in the case of clinoptilolite vs heulandite and vermiculite vs hydrobiotite; this will enable their further use in environmental applications. The methods used in the present study are XRD, XRF, FTIR spectroscopy, TG/DTG/DTA and $\mathrm{N}_{2}$-porosimetry (BET). Data revealed from XRD, FTIR, TG/DTG/DTA showed that all three minerals have characteristic bands that can characterized and distinguish each other. The key difference between Heulandite and Clinoptilolite is their behavior upon heating. Clinoptilolite is stable at temperatures exceeding $450^{\circ} \mathrm{C}$, where heulandites undergo structural collapse below $450^{\circ} \mathrm{C}$. XRF analysis showed that Vermiculite sample is rich in $\mathrm{MgO}$ (Mg-vermiculite) and the low concentration of $\mathrm{K}_{2} \mathrm{O}$ revealed the presence of Vermiculite instead of Hydrobiotite. Thermogravimetric analysis showed that the main regions of Clinoptilolite weight loss are the release of looselybound water $\left(50-200^{\circ} \mathrm{C}\right)$, release of "zeolitic" water $\left(200-700^{\circ} \mathrm{C}\right)$ and finally the collapse of crystal structure (700$900^{\circ} \mathrm{C}$ ). In the range $25-400^{\circ} \mathrm{C}$, the endothermal (DTA diagram) process of dehydration occurred in one step. This reveals the presence of clinoptilolite, because for heulandites dehydration occurs in two steps.

As far as porosity is concerned, all three minerals are generally dominated by micro/mesopores. BET surface area for clinoptilolite is between $17-100 \mathrm{~m} 2 / \mathrm{g}$, for bentonite $22-42 \mathrm{~m}^{2} / \mathrm{g}$ and for vermiculite $7-18 \mathrm{~m}^{2} / \mathrm{g}$. The acquired analytical results enabled the full characterization of the examined minerals, despite their common properties.
\end{abstract}

\section{Introduction}

Worldwide abundance of deposits of zeolites and clays, in relation to their low cost and some specific properties such as their high cation exchange capacity (CEC) and their porous structure, render them as suitable materials for a wide variety of industrial and environmental applications as liquid and gas phase adsorption tools [1-3].

Clinoptilolite is one of the most abundant natural zeolites. Its structure is generally described as an outer tetrahedral framework of silica and alumina, in which migration of water molecules and exchangeable cations $\left(\mathrm{Ca}^{2+}, \mathrm{K}^{+}, \mathrm{Na}^{+}\right)$can occur $[4,5]$. Bentonite rock main component is montmorillonite mineral that consists of clay layers which form lamellar platelets, held together by electrochemical forces. Each platelet is formed from three arranged layers, two tetrahedral silica $\left(\mathrm{SiO}_{2}\right)$ layers around a central octahedral alumina $\left(\mathrm{Al}_{2} \mathrm{O}_{3}\right)$ layer [6]. Vermiculite is typical clay which belongs to the montmorillonite-vermiculite group. The general structure of vermiculite can be described as a silicate sheet consisted of two flat layers of silica and alumina tetrahedral layers joined in an octahedral layer from oxygen, magnesium, iron atoms and hydroxyl molecules [7].

A variety of analytical instruments are used for the structural, physical, and chemical characterization of natural minerals. Among others, the most popular are Fourier Transform Infrared Spectroscopy (FTIR), X-Ray Fluorescence (XRF), X-ray powder diffraction (XRD), Thermo-Gravimetric Analysis (TGA), Differential Thermal Analysis (DTA) and $\mathrm{N}_{2}$-porosimetry.

In the present study, the importance of three different natural minerals (clinoptilolite, bentonite, vermiculite), widely employed in sorption technologies is highlighted. Their analytical characterization is performed using a 
series of analytical instruments. The analytical findings are presented, commented and widely discussed with literature. According to our knowledge, very few studies present such a complete data set. This roadmap of information can be used by environmental scientists, which focus on the study of natural silicate minerals for environmental applications. The present study provides all the necessary steps so as to distinguish the minerals under study, between others with similar characteristics.

\section{Materials and methods}

\subsection{Examined silicate minerals}

Three different natural minerals were used: zeolite (clinoptilolite, $<5 \mathrm{~mm})$, vermiculite $(<5 \mathrm{~mm})$, and bentonite $(<90 \mu \mathrm{m})$. Zeolite and bentonite were supplied by S\&B Industrial Minerals SA (Greece) and vermiculite by IGME (Institute of Geology \& Mineral Exploration, Greece). Clinoptilolite and vermiculite were further crushed and milled into powder $(<90 \mu \mathrm{m})$, prior to further analysis.

\subsection{Mineral characterization methods \\ 2.2.1 FTIR spectroscopy}

An FTIR spectrophotometer (Perkin Elmer 880 spectrometer) was used to measure the infrared absorption on the three mineral samples. The FT-IR spectra in the $4000-400 \mathrm{~cm}^{-1}$ range were recorded for all minerals at room temperature. Samples were prepared by using the standard $\mathrm{KBr}$ pellets method. Solid samples have been milled together with potassium bromide $(\mathrm{KBr})$ to form a fine powder, which was then uniaxially compressed into a thin pellet so as to be further analysed.

\subsubsection{X-Ray Fluorescence}

The samples were grounded $(<90 \mu \mathrm{m})$ to eliminate large and/or inconsistent grain sizes and then compressed into pellets to be subjected to X-Ray Fluorescence analysis, by means of an ARL Advant XP sequential (wavelength dispersive) system. It is noted that prior to getting compressed, vermiculite samples were dried at $105^{\circ} \mathrm{C}$ and kept in a desiccator, as this mineral is particularly hydroscopic and its powders may damage the compression dies by sticking to the metallic walls.

\subsubsection{X-Ray Diffraction}

The powder X-ray diffraction patterns of the mineral samples were recorded on a Siemens D-5000 X-ray powder diffractometer over $2 \theta$ range of $5^{\circ}$ to $55^{\circ}$ at a scanning speed of $2^{\circ}(2 \theta)$ per minute and a step size of $0.05^{\circ}$. The diffractometer was equipped with $\mathrm{Ni}$-filtered $\mathrm{Cu} \mathrm{K}$ radiation source $(8978 \mathrm{eV}$ or $\lambda=1.5418 \AA$ ). The X-ray source was operated at $30 \mathrm{~mA}$ and $40 \mathrm{kV}$. Sample preparation for the X-ray analysis involved gentle grinding of the solid into a fine powder and packing of approximately $0.3-0.5 \mathrm{~g}$ of the sample into an aluminium sample holder with light compression to make it flat and tight.

\subsubsection{TG/DTG/DTA thermal analysis}

DTA and TGA or DTG were obtained simultaneously, by means of a Mettler Toledo 851 thermal analyzer at a heating rate of $10^{\circ} \mathrm{C} / \mathrm{min}$, using air atmosphere. The samples were heated in a platinum crucible in the temperature range of $25-1200^{\circ} \mathrm{C}$.

\subsubsection{Capacity measurements}

Seven types of capacities can be defined [8,9]: ideal exchange capacity, theoretical exchange capacity (TEC), real exchange capacity, maximum exchange level (MEL), operating capacity, breakthrough capacity, and effective capacity. Most commonly used in the characterization of minerals are the TEC and the MEL. A common method for the determination of the theoretical exchange capacity of ion exchangers is the material chemical analysis. For natural minerals containing impurities, which can be active or inactive in respect to ion exchange, TEC is expressing the amount of potential exchangeable cations. The most common exchangeable cations are $\mathrm{Mg}, \mathrm{Ca}$, $\mathrm{K}$, and Na. Thus, TEC is the total sum of the mineral exchangeable cations. MEL is a characteristic property of the specific ion-exchange system. An ion-exchange system, is defined as a system consisting of a material and a liquid solution which contains the ion to be exchanged, under a specified temperature and normality. MEL is straightforwardly related to the equilibrium behavior of the specific ion-exchange system and like the equilibrium isotherm depends only on the temperature and the normality of the solution. MEL is measured by repeated equilibrations or by determinations using equilibrium data (equilibrium isotherm) and is expressed in terms of exchangeable ions per unit mass of the exchange material [8]. In the present study, MEL experiments were conducted as follows: a measured quantity of zeolite, bentonite or vermiculite $(0.2-0.8 \mathrm{~g})$ was added in a vessel containing measured volume of metal solutions $\left(100 \mathrm{~cm}^{3}\right)$ at the initial concentration of $0,01 \mathrm{~N}$, with $\mathrm{pH}$ initial adjustment $(\mathrm{pH}=4)$. Every 7 days the solution was analyzed for metal concentrations and then replaced with fresh solution of the same metal, until no further uptake from mineral was observed. 


\subsubsection{Specific surface area and porosity}

The most widely used technique for estimating surface area is the so-called BET method [10]. BET is a wellknown equilibrium model for the physical adsorption of gas molecules on a solid surface and is the basis for the measurement of the specific surface area (SSA) of a material $[10,11]$. The SSA and the pore characteristics of minerals were determined volumetrically by physisorption of $\mathrm{N}_{2}$ at normal boiling point temperature $(77 \mathrm{~K})$ in a static mode using a Nova-2000 6.11 Quantachrome instrument.

\section{Results and Discussion}

\subsection{FTIR Spectroscopy}

Natural minerals, such as zeolites, montmorillonites and vermiculites, are used in ion-exchange systems because of specific characteristics regarding their structure, channel size, and cation substitution in the tetrahedral sites of the minerals, which makes them proper materials for such systems. FTIR spectroscopy is powerful for the chemical composition and identification of the functional groups of minerals [12].

The main findings by the FTIR spectroscopy characterization of the examined zeolite samples (figure 1) are summarized below:

1. Bands attributed to zeolite water in the region of $3700-1600 \mathrm{~cm}^{-1}$ :

a) $\mathrm{OH}$-stretching: the band of zeolite under study is found at $\sim 3622 \mathrm{~cm}^{-1}$, which is attributed to the interactions of the water hydroxyl with the cations. In the literature, results showed very close bands for clinoptilolite and heulandite, with values close to $3620 \mathrm{~cm}^{-1}$.

b) Hydrogen bonding of the water to surface oxygen: the band of zeolite under study is found at $\sim 3446 \mathrm{~cm}^{-}$

${ }^{1}$. Results from literature, show that bands for clinoptilolite and heulandite are very close, with values in the range of $3413 \mathrm{~cm}^{-1}-3459 \mathrm{~cm}^{-1}$ for clinoptilolite, $3420 \mathrm{~cm}^{-1}$ for heulandite and $3437 \mathrm{~cm}^{-1}-3450 \mathrm{~cm}^{-1}$ for heulandite type-II.

c) OH-bending: bending mode of the water is found at $\sim 1635 \mathrm{~cm}^{-1}$. Literature data shows that clinoptilolite bands are from $1630 \mathrm{~cm}^{-1}$ to $1650 \mathrm{~cm}^{-1}$, heulandite bands are in the same range, while heulandite values close to $1638 \mathrm{~cm}^{-1}-1640 \mathrm{~cm}^{-1}$.

2. Bands attributed to the $\mathrm{Si}-\mathrm{O}-\mathrm{Si}$ and $\mathrm{Si}-\mathrm{O}-\mathrm{Al}$ vibrations in the regions $1200-950 \mathrm{~cm}^{-1}$ and $420-500 \mathrm{~cm}^{-1}$ :

a) Asymmetric $\mathrm{T}-\mathrm{O}$ stretching: The strongest $\mathrm{T}-\mathrm{O}$ stretching vibration appears at $1036 \mathrm{~cm}^{-1}$, which as Perraki and Orfanoudaki reported [12], is a very significant band for the estimation of aluminum content in the crystalline framework and it depends on the $\mathrm{Al} / \mathrm{Si}$ ratio. It shifts to a lower wave number with increasing number of $\mathrm{Al}$ atoms in the tetrahedral sites [12]. In general, clinoptilolites have less $\mathrm{Al}$ atoms per formula unit in relation to heulandites and TO-stretching band is expected to be found in higher wavelength values than in heulandites. Comparing these results with other data from literature, it can be seen that in general heulandites are indeed in lower wavelength values $\left(1022-1030 \mathrm{~cm}^{-1}\right)$, where clinoptilolites are in higher ones but some are very close to heulandites $\left(1032-1088 \mathrm{~cm}^{-1}\right)$.

b) Symmetric T-O stretching: Most bands found in the literature are close to $670 \mathrm{~cm}^{-1}$.

c) T-O bending: Clinoptilolite bands are from $461 \mathrm{~cm}^{-1}$ to $480 \mathrm{~cm}^{-1}$, in relation to heulandite bands that are from $440-466 \mathrm{~cm}^{-1}$ and heulandite type II from $420-500 \mathrm{~cm}^{-1}$.

3. Pseudo-lattice vibrations: In the pseudo-lattice band range, the exact position of the vibration is found at 610 $\mathrm{cm}^{-1}$. In the literature clinoptilolite bands are in the range of $602 \mathrm{~cm}^{-1}-615 \mathrm{~cm}^{-1}$, heulandite bands $594 \mathrm{~cm}^{-1}$ $604 \mathrm{~cm}^{-1}$ and heulandite type-II at $597 \mathrm{~cm}^{-1}$. 


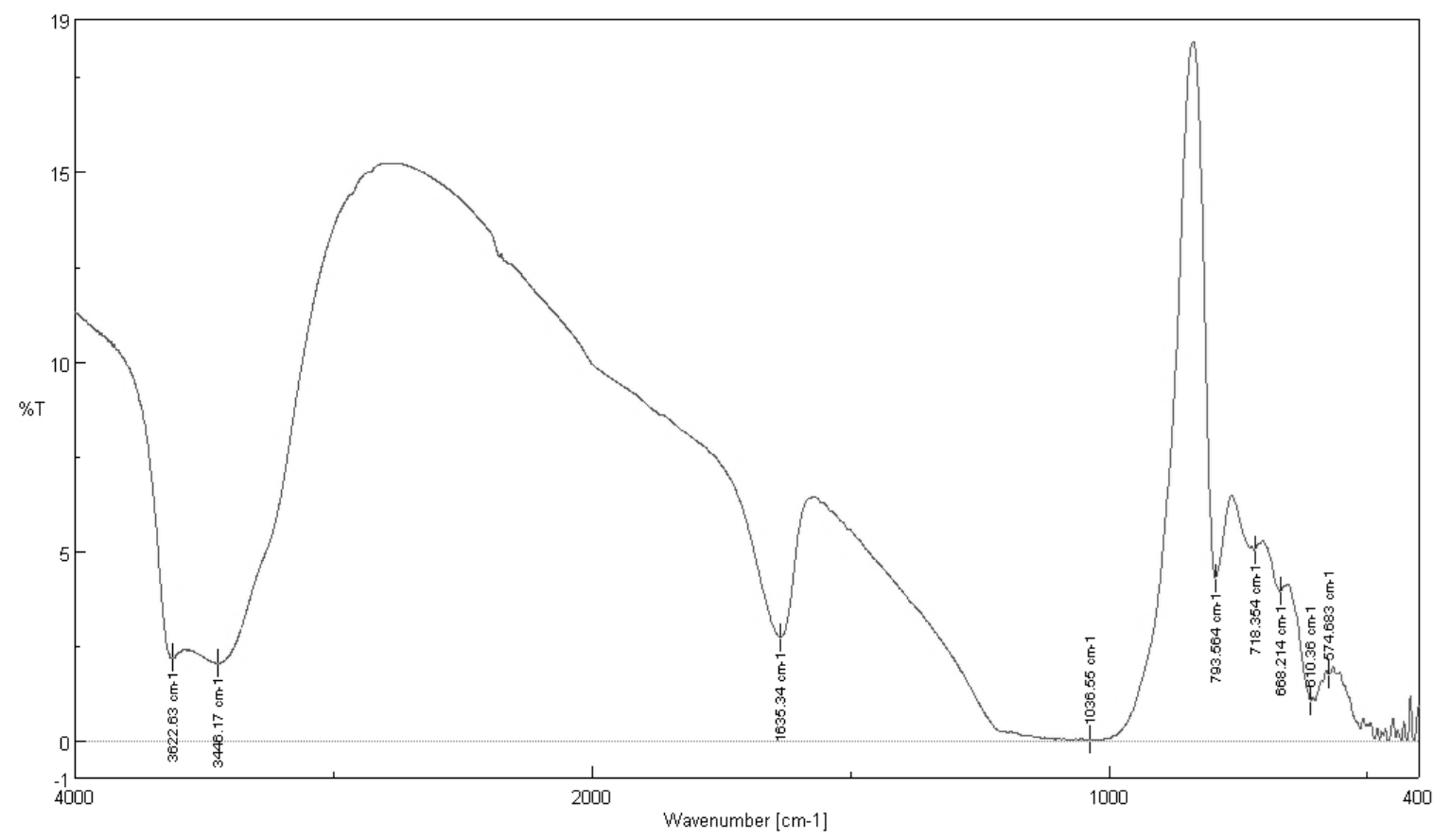

Figure 1. FTIR spectra of clinoptilolite

Fig. 2, shows the FTIR spectra of bentonite as determined in the current study. In the bentonite band, the vibrations given at $469 \mathrm{~cm}^{-1}$ and $522 \mathrm{~cm}^{-1}$ are due to the absorption of the characteristic bond of Si-O-Si and Si-O-Al ${ }^{\mathrm{vi}}$, whereas the vibrations given at $878 \mathrm{~cm}^{-1}$ and $917 \mathrm{~cm}^{-1}$ and $3628 \mathrm{~cm}^{-1}$, are due to the $\mathrm{Al}{ }^{\mathrm{vi}}-\mathrm{OH}-\mathrm{R}^{\mathrm{vi}}$, (where R: A1 ${ }^{3+}$, $\mathrm{Mg}^{2+}, \mathrm{Fe}^{3+} \eta \mathrm{Fe}^{2+}$ ) [13]. Perraki and Orfanoudaki [13], reported that the vibration given at $543 \mathrm{~cm}^{-1}$ is characteristic of the Si-O-Al ${ }^{\text {vi }}$ bond and that its exact position depends on the cation that occupies the octahedral position. When substitution of $\mathrm{Al}^{\text {vi }}$ by $\mathrm{Mg}^{2+}$ takes place ( $\mathrm{Si}-\mathrm{O}-\mathrm{Mg}^{2+}$ bond), a shift to lower vibration positions turns up [13, 14]. The vibration given at $917 \mathrm{~cm}^{-1}$ refers to the $\mathrm{Al}^{\mathrm{vi}}-\mathrm{OH}-\mathrm{Al}^{\text {vi }}$ bond and corresponds to pure montmorillonite. Smectites with high content of $\mathrm{Mg}$, as a substitution of $\mathrm{Al}^{\mathrm{vi}}\left(\mathrm{Al}^{\mathrm{vi}}-\mathrm{OH}-\mathrm{Mg}\right)$, vibrate at lower frequencies $\left(845 \mathrm{~cm}^{-}\right.$ ${ }^{1}$ ). Smectites that contain $\mathrm{Fe}$, as a substitution of $\mathrm{Al}^{\mathrm{vi}}\left(\mathrm{Al}^{\mathrm{vi}}-\mathrm{OH}-\mathrm{Fe}^{\mathrm{vi}}\right)$, show vibration at $\sim 870 \mathrm{~cm}^{-1}$. In the region of $3600 \mathrm{~cm}^{-1}$ to $3700 \mathrm{~cm}^{-1}$, the vibration at $3628 \mathrm{~cm}^{-1}$ characterizes the group of $\mathrm{Al}^{\mathrm{vi}}-\mathrm{OH}-\mathrm{Al}^{\mathrm{vi}}$ [13]. The low vibration at $878 \mathrm{~cm}^{-1}$ indicates low substitution of $\mathrm{Al}^{\mathrm{vi}}$ by $\mathrm{Fe}^{3+}$. Finally, the wide vibration at $3446 \mathrm{~cm}^{-1}$, and the sharp vibration at $1637 \mathrm{~cm}^{-1}$ are attributed to the adsorbed water.

Fig. 3, shows the FTIR spectra of vermiculite. In vermiculite band, the vibrations given at $3419 \mathrm{~cm}^{-1}$, are characteristic of hydroxyl stretching vibration $\left(\mathrm{OH}\right.$ stretch) and at $1646 \mathrm{~cm}^{-1}$ characteristic of hydroxyl bending vibration (OH band). The vibrations at $1013 \mathrm{~cm}^{-1}$ and $457 \mathrm{~cm}^{-1}$ are due to Si-O stretching and Si-O-Si bending, respectively. Interferences to the IR band of clay minerals, such as montmorillonite and vermiculite, may occur due to impurities in the raw material. In the IR studies of clay, the Si-O stretching vibrations were observed at $791 \mathrm{~cm}^{-1}, 693 \mathrm{~cm}^{-1}, 539 \mathrm{~cm}^{-1}$ and $469 \mathrm{~cm}^{-1}$, showing the presence of quartz. The appearance of $v(\mathrm{Si}-\mathrm{O}-\mathrm{Si}$ ) and $\delta$ ( $\mathrm{Si}-\mathrm{O}$ ) bands also support the presence of quartz. Most of the bands reported in the literature, such as at $3697 \mathrm{~cm}^{-}$ ${ }^{1}, 3623 \mathrm{~cm}^{-1}, 3450 \mathrm{~cm}^{-1}, 1033 \mathrm{~cm}^{-1}, 915 \mathrm{~cm}^{-1}, 791 \mathrm{~cm}^{-1}, 693 \mathrm{~cm}^{-1}, 539 \mathrm{~cm}^{-1}, 469 \mathrm{~cm}^{-1}$ are indicative of the presence of kaolinite. Furthermore, other studies in the literature report that the vibrations observed at $915 \mathrm{~cm}^{-1}$ indicate the possibility of the presence of hematite. Also, the presence of bands at $3697 \mathrm{~cm}^{-1}, 3623 \mathrm{~cm}^{-1}, 3450 \mathrm{~cm}^{-1}, 2370 \mathrm{~cm}^{-}$ ${ }^{1}, 1633 \mathrm{~cm}^{-1}, 1033 \mathrm{~cm}^{-1}, 915 \mathrm{~cm}^{-1}$ and $791 \mathrm{~cm}^{-1}$ indicate the possibility of the presence of illite, whereas $3623 \mathrm{~cm}^{-}$ ${ }^{1}, 1633 \mathrm{~cm}^{-1}, 1033 \mathrm{~cm}^{-1}$ are indicative of gypsum and $693 \mathrm{~cm}^{-1}$ suggests that calcite may be present [15]. 


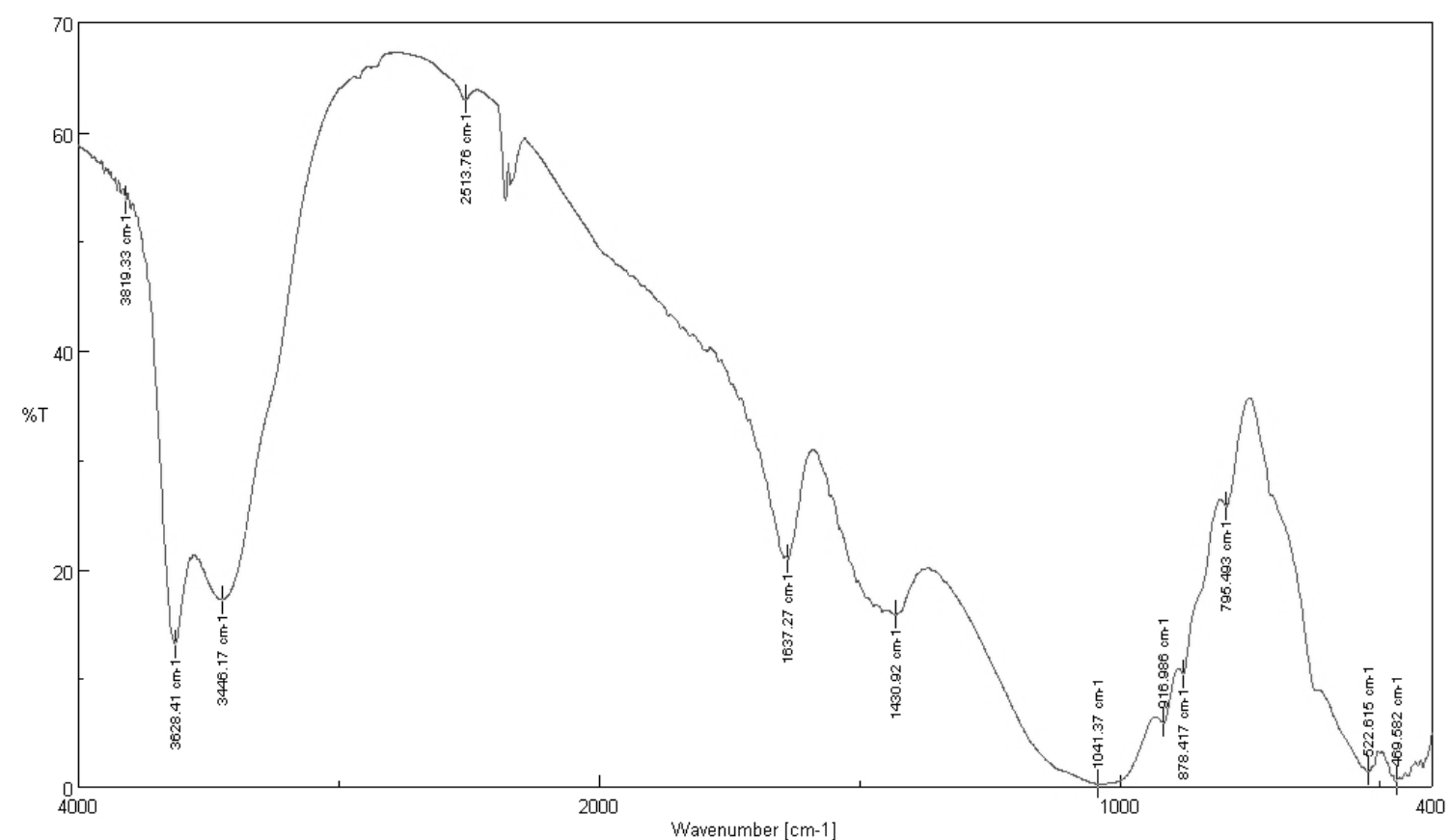

Figure 2. FTIR spectra of bentonite.

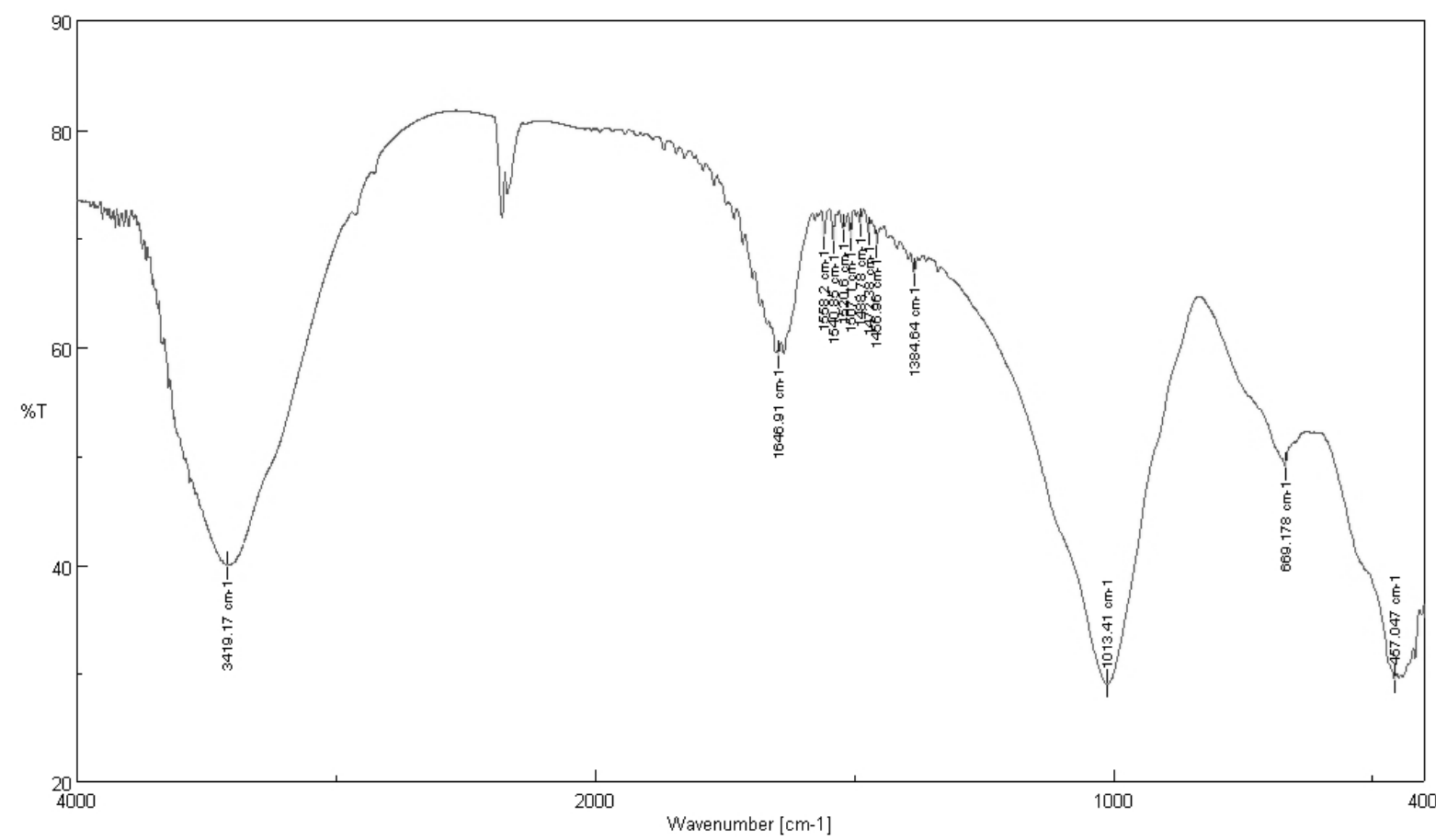

Figure 3. FTIR spectra of vermiculite.

\subsection{X-Ray Fluorescence and Capacity measurements}

\subsubsection{X-Ray Fluorescence (XRF)}

Table 1 shows the XRF results as determined in the present study. The overall $\mathrm{Si} / \mathrm{Al}$ ratio for zeolite samples is higher than 4. As mentioned in literature, minerals with $\mathrm{Si} / \mathrm{Al}$ ratio $<4$ are classified as heulandites, whereas $\mathrm{Si} / \mathrm{Al}$ $>4$ is indicative of clinoptilolites $[4,16]$. The $\mathrm{SiO}_{2}+\mathrm{Al}_{2} \mathrm{O}_{3}$ is higher than $75 \%$; the rest being water and exchangeable cations. Bentonite samples show $\mathrm{Si} / \mathrm{Al}$ ratio lower than 4 , while $\mathrm{SiO}_{2}+\mathrm{Al}_{2} \mathrm{O}_{3}$ is higher than $65 \%$, and in general lower than clinoptilolite samples. Finally, vermiculite samples show Si/Al ratio lower than 4, while $\mathrm{SiO}_{2}+\mathrm{Al}_{2} \mathrm{O}_{3}$ is higher than $50 \%$, and in general lower than clinoptilolite and bentonite samples. XRF analysis showed that vermiculite sample is rich in $\mathrm{MgO}$ (Mg-vermiculite) and low concentration of $\mathrm{K}_{2} \mathrm{O}$ revealed the presence of vermiculite instead of hydrobiotite. 
Table 1. Chemical analysis of minerals by XRF.

\begin{tabular}{|c|c|c|c|c|c|c|}
\hline & \multicolumn{2}{|c|}{ Zeolite } & \multicolumn{2}{|c|}{ Bentonite } & \multicolumn{2}{|c|}{ Vermiculite } \\
\hline & $\% w / w$ & meq/g & $\% w / w$ & meq/g & $\% w / w$ & meq/g \\
\hline $\mathrm{SiO}_{2}$ & 70.1 & & 55.9 & & 47 & \\
\hline $\mathrm{Al}_{2} \mathrm{O}_{3}$ & 12.0 & & 18.0 & & 16.6 & \\
\hline $\mathrm{Fe}_{2} \mathrm{O}_{3}$ & 0.727 & & 3.85 & & 12.3 & \\
\hline $\mathrm{CaO}$ & 3.04 & 1,084 & 3.63 & 1.295 & 0.575 & 0.207 \\
\hline MgO & 0.765 & 0,382 & 3.53 & 1.752 & 21.6 & 10.718 \\
\hline $\mathrm{Na}_{2} \mathrm{O}$ & 0.304 & 0.097 & 3.52 & 1.136 & -- & -- \\
\hline $\mathrm{SO}_{3}$ & 140 ppm & & 1.20 & & $270 \mathrm{ppm}$ & \\
\hline $\mathrm{TiO}_{2}$ & 0.113 & & 0.706 & & 0.922 & \\
\hline $\mathrm{K}_{2} \mathrm{O}$ & 3.31 & 0,703 & 0.611 & 0.130 & 0.350 & 0.074 \\
\hline $\mathrm{P}_{2} \mathrm{O}_{5}$ & -- & & 0.136 & & $520 \mathrm{ppm}$ & \\
\hline Cl & 52 ppm & & $550 \mathrm{ppm}$ & & -- & \\
\hline MnO & $440 \mathrm{ppm}$ & & $450 \mathrm{ppm}$ & & 0.150 & \\
\hline $\mathbf{B a O}$ & -- & & $280 \mathrm{ppm}$ & & $210 \mathrm{ppm}$ & \\
\hline $\mathrm{V}_{2} \mathrm{O}_{5}$ & $270 \mathrm{ppm}$ & & 280 ppm & & 89 ppm & \\
\hline $\mathrm{ZnO}$ & 38 ppm & & 49 ppm & & 270 ppm & \\
\hline $\mathrm{NiO}$ & $15 \mathrm{ppm}$ & & $33 \mathrm{ppm}$ & & 0.172 & \\
\hline SrO & $130 \mathrm{ppm}$ & & $32 \mathrm{ppm}$ & & $25 \mathrm{ppm}$ & \\
\hline $\mathrm{CuO}$ & -- & & $25 \mathrm{ppm}$ & & -- & \\
\hline $\mathrm{Cr}_{2} \mathrm{O}_{3}$ & -- & & $18 \mathrm{ppm}$ & & 0.254 & \\
\hline $\mathbf{R} \mathbf{b}_{2} \mathbf{O}$ & 93 ppm & & $15 \mathrm{ppm}$ & & -- & \\
\hline $\mathrm{ZrO}_{2}$ & -- & & $12 \mathrm{ppm}$ & & -- & \\
\hline $\mathrm{Ag}_{2} \mathrm{O}$ & -- & & 2 ppm & & -- & \\
\hline PbO & $13 \mathrm{ppm}$ & & -- & & -- & \\
\hline $\mathrm{Co}_{3} \mathrm{O}_{4}$ & -- & & -- & & $120 \mathrm{ppm}$ & \\
\hline $\mathrm{Nb}_{2} \mathrm{O}_{5}$ & -- & & -- & & 21 ppm & \\
\hline LOI* $^{*}$ & 9.45 & & 8.75 & & -- & \\
\hline
\end{tabular}

*LOI: mass loss upon firing at $1100^{\circ} \mathrm{C}$.

\subsection{X-Ray Diffraction}

\subsubsection{Zeolite Mineralogy}

Fig. 4 shows the diffraction spectra of the examined zeolite. The parental material is identified as clinoptilolite $\left((\mathrm{Na}, \mathrm{K}, \mathrm{Ca})_{5} \mathrm{Al}_{6} \mathrm{Si}_{30} \mathrm{O}_{72} .18 \mathrm{H}_{2} \mathrm{O}\right)$, and its characteristic peaks were recognized at $2 \theta=9.87^{\circ}$ (d spacing: $8.94 \AA$ ), $22.487^{\circ}(\mathrm{d}=3.95 \AA)$ and $30.360^{\circ}(\mathrm{d}=2.94 \AA)$. The sample also contains small amounts of mica/illite, cristobalite $\left(\mathrm{SiO}_{2}\right)$, dolomite $\left(\mathrm{CaMg}\left(\mathrm{CO}_{3}\right)_{2}\right)$ and feldspar [albite $(\mathrm{Na}, \mathrm{Ca})(\mathrm{Si}, \mathrm{Al})_{4} \mathrm{O}_{8} /$ anorthite $\left.(\mathrm{Ca}, \mathrm{Na})(\mathrm{Si}, \mathrm{Al})_{4} \mathrm{O}_{8}\right]$ (possibly). The characteristic peaks found in the present study are similar to other studies, as shown in the litterature, which are typical for clinoptilolite samples. As reported by Perraki et al. [17], in heulandite the highest peak is attributed to the $(020)$ reflection $(d=8.99 \AA)$, whereas in clinoptilolite the higher peak is attributed to the $(040)$ reflection $(\mathrm{d}=3.98 \AA)$ [17]. The $(020)$ reflection of heulandite at $9.9^{\circ} 2 \theta$ is always far more intense than the remaining lines of the pattern, while this same reflection in X-Ray tracings of clinoptilolite is, in many samples, exceeded in intensity by the (004) peak at about $22.3^{\circ} 2 \theta$. The differences between diffractometer tracings of clinoptilolite and heulandite have been reported sufficient for distinguishing these two similar zeolites [18]. The thermal behavior of the zeolite samples in conjunction to XRD analysis, shown in Fig. 5, has been studied in a wide range of temperatures (25-400-540-600-740-940 ${ }^{\circ} \mathrm{C}$ ). The key difference between heulandites and clinoptilolite is their behavior upon heating. Clinoptilolite is stable at temperatures exceeding $450^{\circ} \mathrm{C}$; heulandites undergo structural collapse below $450^{\circ} \mathrm{C}$ [19]. A partial framework breakdown indicates the presence of an intermediate member of the heulandite-clinoptilolite isomorphous series, "heulandite type-II" [17]. 


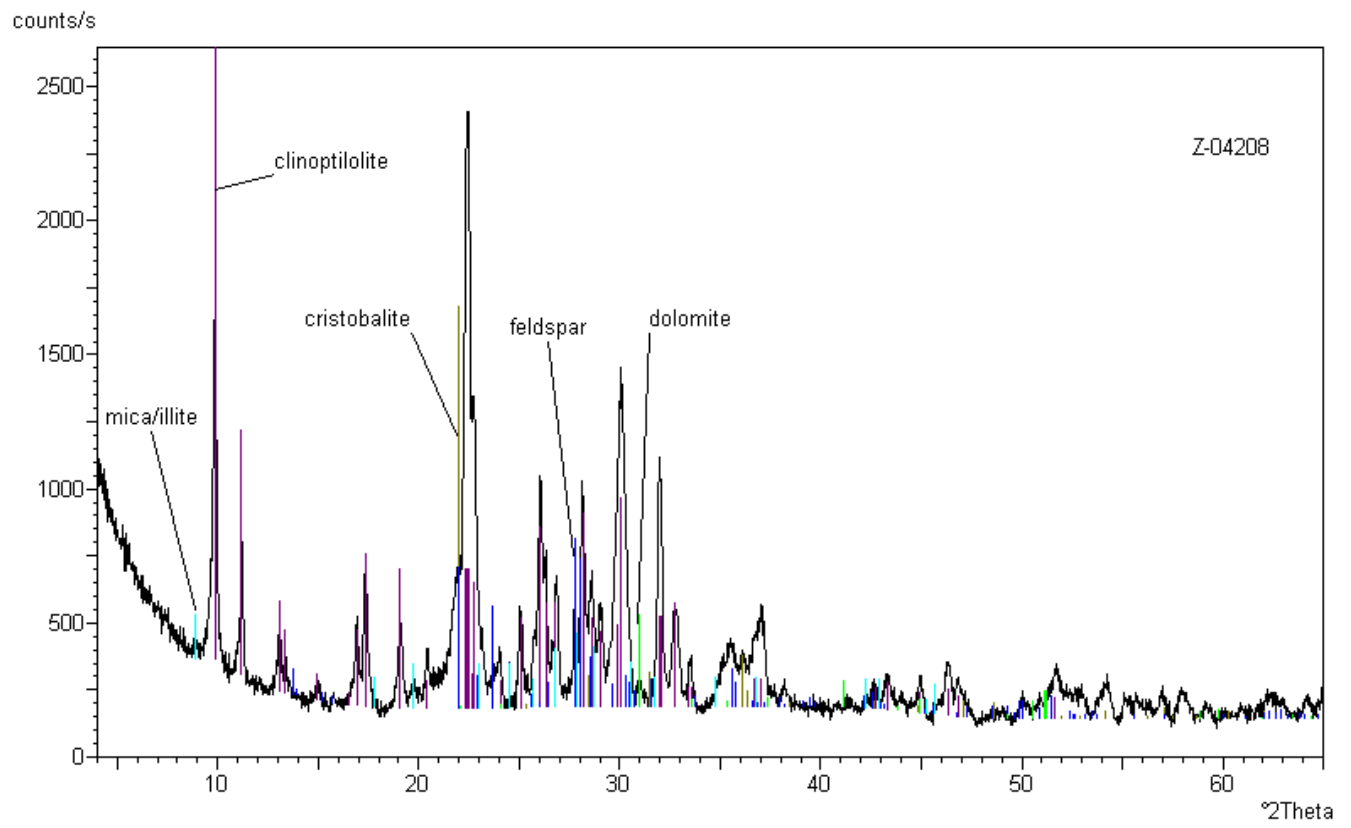

Figure 4. XRD pattern of clinoptilolite.

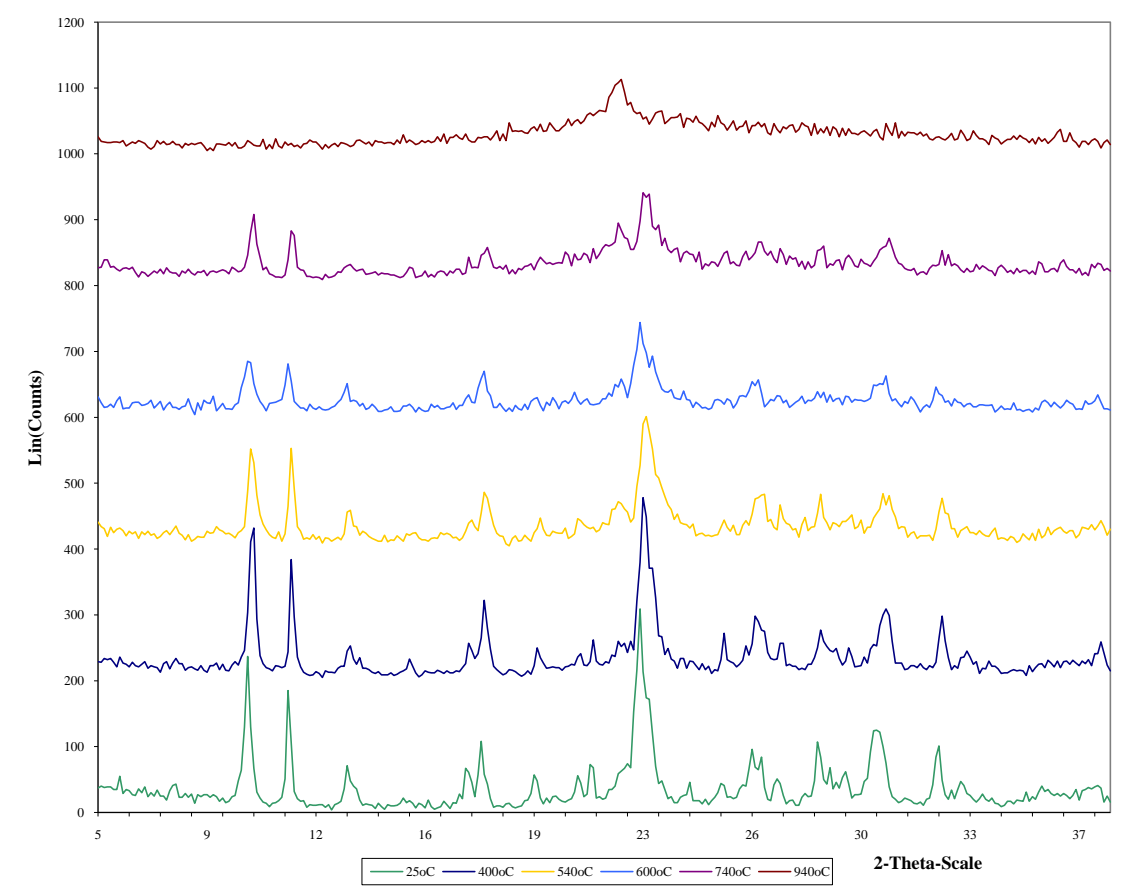

Figure 5. XRD patterns of clinoptilolite vs temperature pretreatment.

3.3.2 Mineralogy of bentonite and vermiculite

The XRD pattern of the natural bentonite (Fig. 6) shows reflection peaks at about $2 \theta=7.28^{\circ}-13.29^{\circ}-19.91^{\circ}-28.5^{\circ}$, corresponding to a spacing of 12.13-6.66-4.46-3.13 $\AA$. These reflections are attributed to montmorillonite, which is the main component of the mineral, with concentration up to $\sim 76 \%$ wt. Small amounts of mica/illite, dolomite $\left(2 \theta=31.120^{\circ}-\mathrm{d}=2.87\right)\left[\mathrm{CaMg}\left(\mathrm{CO}_{3}\right)_{2}\right]$, calcite $\left(2 \theta=29.74^{\circ}-\mathrm{d}=3\right)\left[\mathrm{CaCO}_{3}\right]$, quartz $\left(2 \theta=26.921^{\circ}-\mathrm{d}=3.30915\right)\left[\mathrm{SiO}_{2}\right]$, anatase $\left(2 \theta=25.55^{\circ}-\mathrm{d}=3.48\right)\left[\mathrm{TiO}_{2}\right]$ and pyrite $\left(2 \theta=33.3^{\circ}-\mathrm{d}=2.69\right)\left[\mathrm{FeS}_{2}\right]$ have been also identified. Mineralogy of bentonite samples (XRD) can be connected with the chemical analysis of the mineral (XRF), and more specifically, the reflection peaks of an XRD pattern are connected to the elemental content in the structure of the mineral [13]. Perraki and Orfanoudaki [13], reported that in minerals rich in calcium (Ca-montmorillonite), the 
main reflection peak is $d(001) d \sim 15 \AA$, but when it is referred to as a sodium form (Na-montmorillonite), the corresponding peak is $\mathrm{d}(001) \sim 12.5 \AA$.

The XRD pattern of natural vermiculite (Fig. 7) shows reflection peaks at about $2 \theta=6.15^{\circ}-24.71^{\circ}-31.05^{\circ}$, corresponding to a basal d spacing of $14.35 \AA$, $3.59977 \AA$ and $2.88 \AA$. Perez-Maqueda et al. [20], studied three different vermiculite samples $\left(\mathrm{Mg}, \mathrm{Na}\right.$ and $\mathrm{NH}_{4}$ vermiculite) in different temperatures and showed that upon heating the interlayer distances decreased.

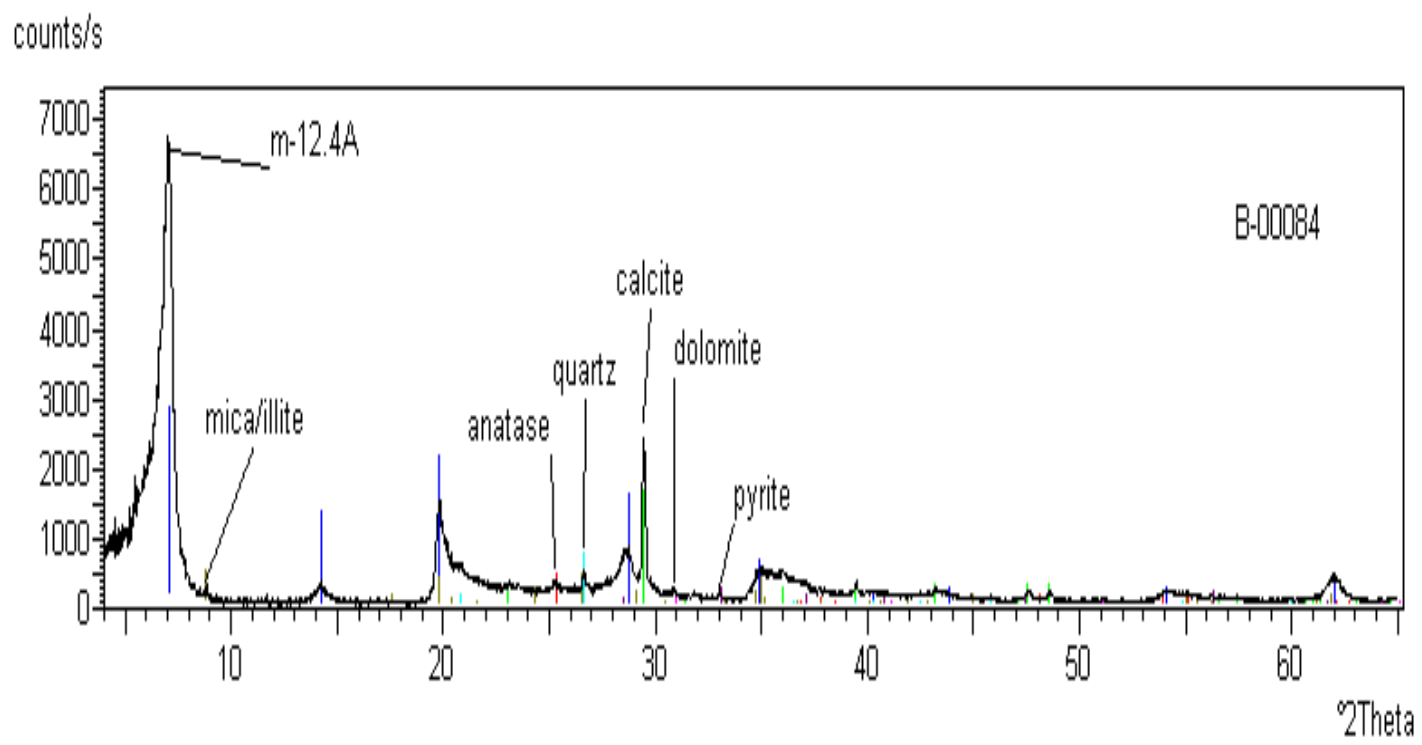

Figure 6. XRD pattern of bentonite.

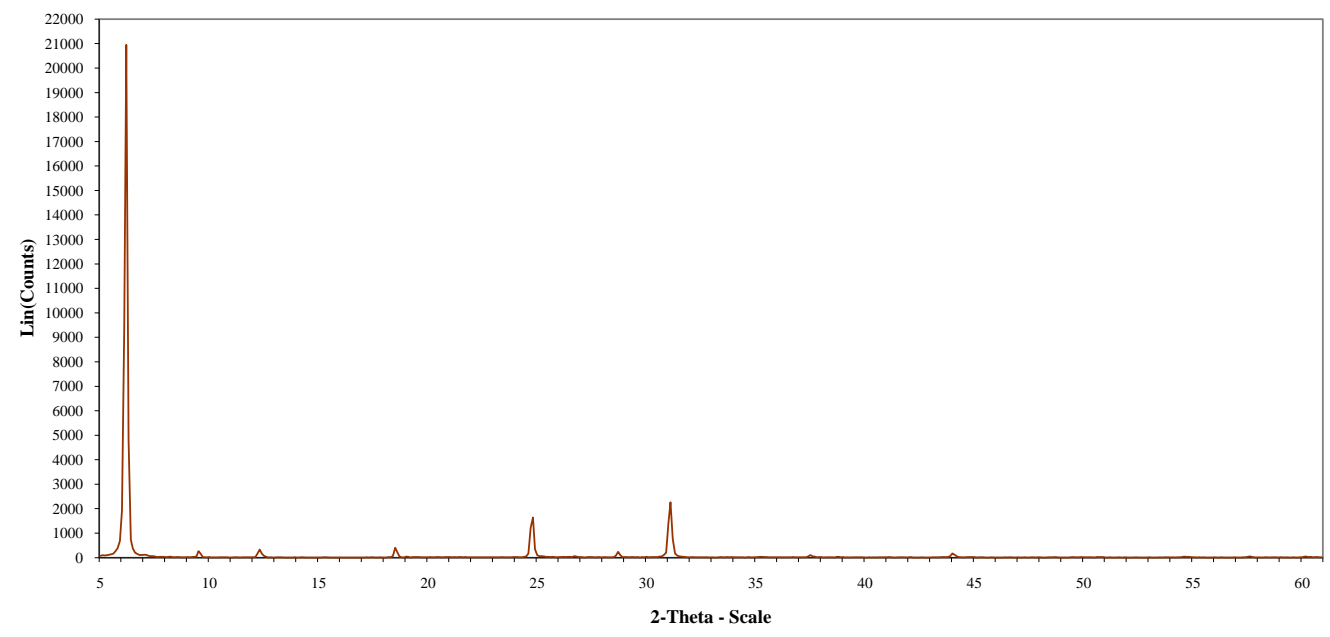

Figure 7. XRD pattern of vermiculite.

\subsection{Thermal analysis of minerals}

\subsubsection{Thermal characterization of zeolite}

Taking into account the dehydration behavior of zeolites, they can be distinguished into two main categories; the ones that do not show major structural changes and those that undergo structural changes with dehydration [21]. According to the literature, heulandite/clinoptilolite zeolites can be classified into three different types according to their thermal behavior. According to these types, information regarding their framework contraction and reversible dehydration, irreversible structural changes, hindered rehydration and structure collapse upon heating $\left(>450^{\circ} \mathrm{C} ;>550^{\circ} \mathrm{C} ;>750^{\circ} \mathrm{C}\right.$ respectively) can be obtained [21]. In general, thermal stability of a mineral increases with increasing $\mathrm{Si} / \mathrm{Al}$ ratio, because more energy is required to break the $\mathrm{Si}-\mathrm{O}$ bond compared to the $\mathrm{Al}-\mathrm{O}$ bond [21].

The TG/DTA and weight loss curves of the zeolite sample are presented in Fig. 8. The TG curve of the examined sample showed a rather continuous weight loss behavior when heated up to $700^{\circ} \mathrm{C}$, due to the loss of the 
hygroscopic water $\left(25-100^{\circ} \mathrm{C}\right)$ and the loss of water residing in the channels and the cavities of the zeolite framework. The most important aspects of zeolite thermal analysis reported in literature and confirmed by the current study are summarized below:

- In the range $25-400^{\circ} \mathrm{C}$, the endothermal (DTA diagram) process of dehydration occurs in two steps for heulandites samples, but in one step for clinoptilolites [17, 22].

- The process of dehydration, occurring in two separated steps, corresponds to the classification of water into two groups according to its bond strength with cations. Regarding channels, first to leave is the weakly bonded water, whose content varies with the type of cation and the degree of occupancy of particular cationic sites. The water molecules strongly bonded with cations leave at a higher temperature [22].

- At the beginning of the heating process and up to $200^{\circ} \mathrm{C}$ the recorded weight loss corresponds to weakly bound water. The weight loss at between $250^{\circ} \mathrm{C}$ and $400^{\circ} \mathrm{C}$ is attributed to the dehydroxylation reaction $\left(2 \mathrm{OH}^{-}\right.$ $\rightarrow \mathrm{O}^{2-}+\mathrm{H}_{2} \mathrm{O}$ ), and it occurs for solids which contain structural $\mathrm{OH}$. There is also a third weight loss region $\left(450-500^{\circ} \mathrm{C}\right)$, which corresponds to structural water and to the destruction of zeolitic structure [23].

- In the range of $400-1000^{\circ} \mathrm{C}$, several exothermic peaks can be observed in DTA and DTG curves, which correspond to transformations or even collapse of the crystal structure of zeolites.

- The DTA curve of heulandite shows an endothermic reaction at $200^{\circ} \mathrm{C}$, followed by a stronger endothermic peak at $360^{\circ} \mathrm{C}$, while the DTA curve of clinoptilolite shows a broad endothermic peak at around $200^{\circ} \mathrm{C}$ [17]. If the differences in thermal stability between heulandites and crinoptilolites are solely due to the nature of the exchangeable cation in each species, one might expect a calcium-exchanged clinoptilolite to exhibit the low temperature reactions and low thermal stability of heulandite. Inversely, a sodium-exchanged heulandite should be more thermally stable than the calcium variety [18].

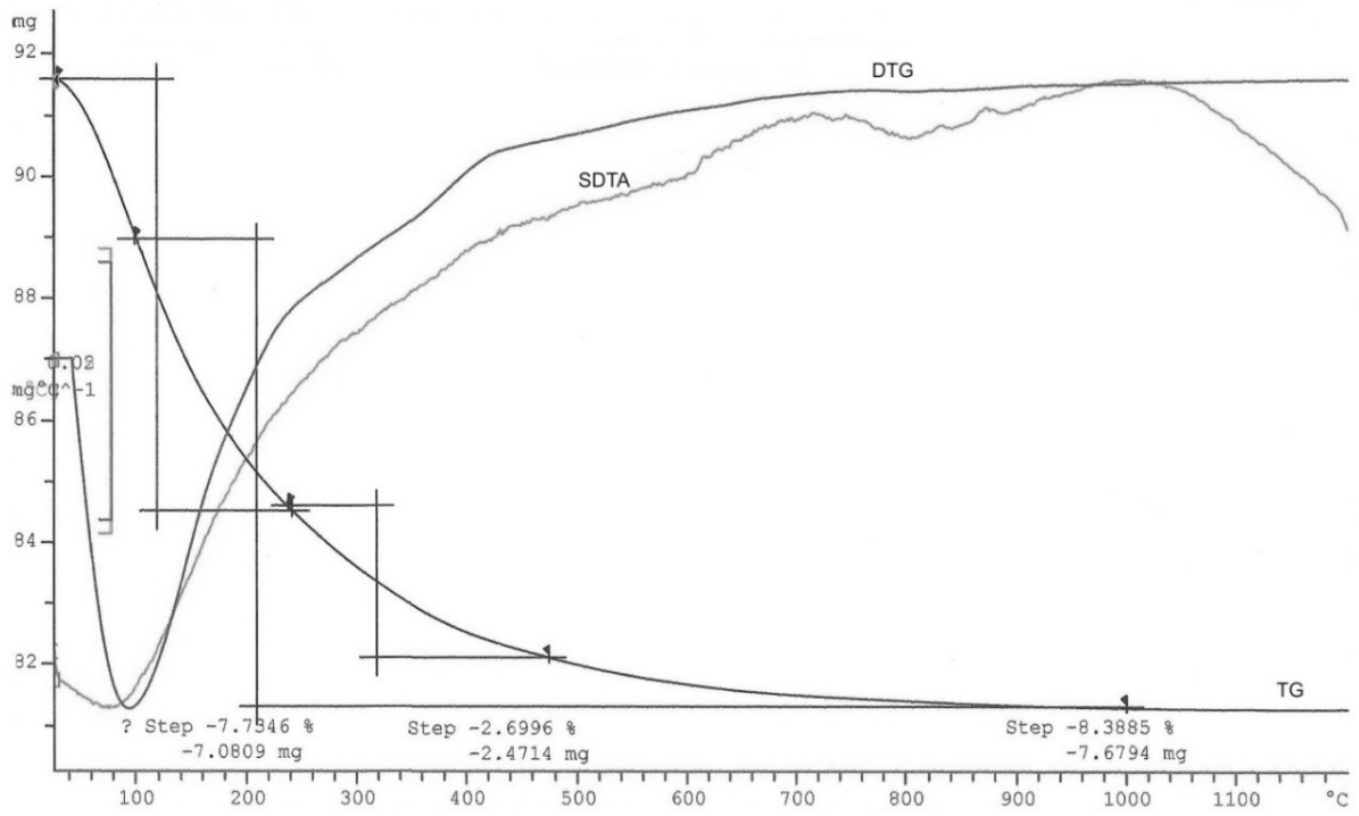

Figure 8. TG/DTA curves for clinoptilolite.

\subsubsection{Thermal characterization of bentonite}

The most important observations regarding bentonite thermal analysis (Fig. 9) are summarized as follows:

- In most DTA curves, some endothermic peaks are observed between $100-400^{\circ} \mathrm{C}$, which is the result of dehydration. The endothermic peak which results from dehydroxylation and the exothermic peak which results from recrystallization are observed at $600-800^{\circ} \mathrm{C}$. The exothermic peak resulting from the loss of the crystal structure of the 2:1 layers of CaM and recrystallization is observed at $950-1050{ }^{\circ} \mathrm{C}$ [24].

- Tabak et al. [25], reported that the noticeable differences between the mass losses of two untreated bentonites (Wyoming and Resadiye) in the temperature interval $210-550^{\circ} \mathrm{C}$, are attributed to the existence of external clay components such as dolomite, $\alpha$-cristobalite, quartz, calcite, and illite of Resadiye bentonite [25].

- Above $900^{\circ} \mathrm{C}$, all major structural changes result in the development of cristobalite and mullite in montmorillonite [26]. 


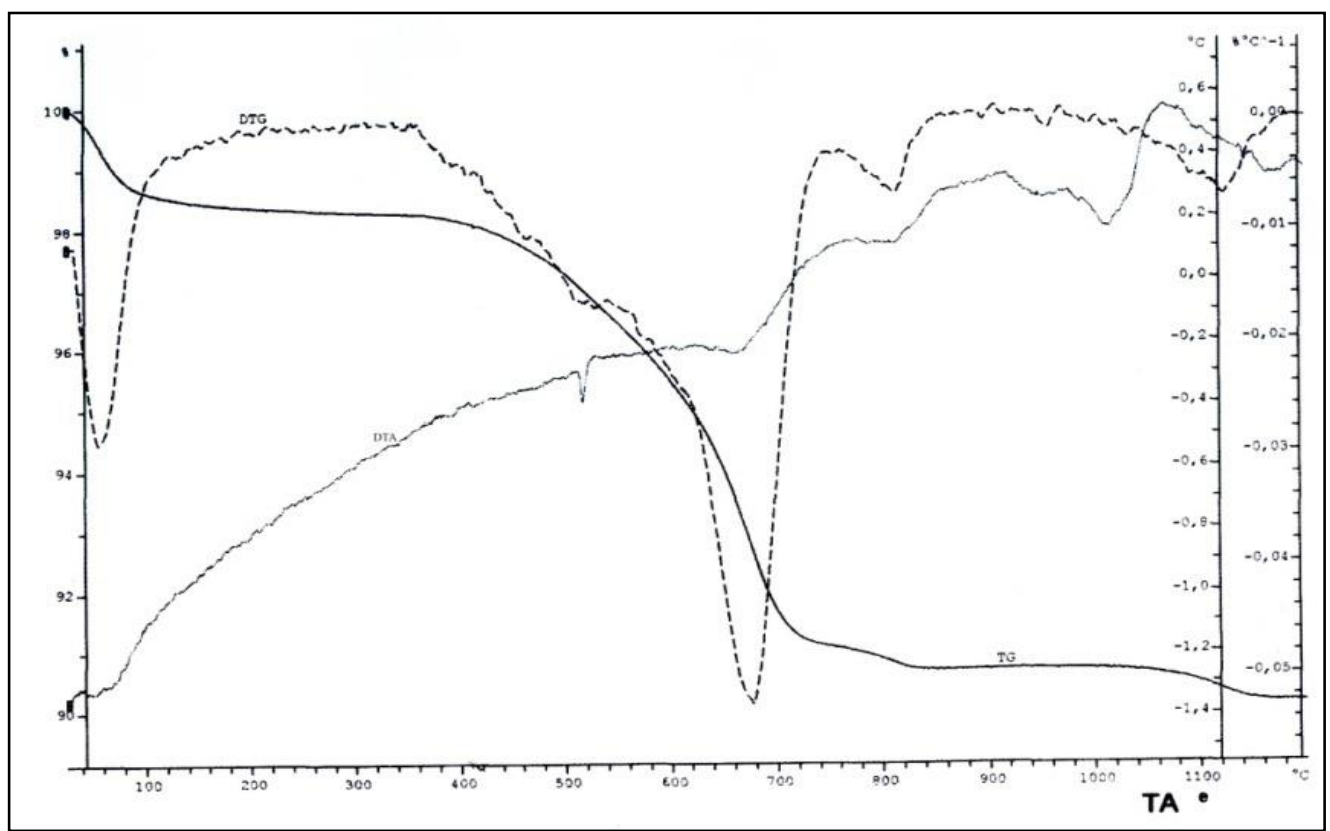

Figure 9. TG/DTA curves for bentonite.

3.4.3 Thermal characterization of vermiculite

Pure vermiculites show large endothermic effects at $145-150^{\circ} \mathrm{C}$ with smaller ones at $260-270^{\circ} \mathrm{C}$ and correspond to $\mathrm{Mg}$-vermiculites. Some samples show a small endothermic effect at about $550^{\circ} \mathrm{C}$ and a corresponding weight loss on the TG curve, which are attributed to dehydroxylation of mica present in vermiculite. Other samples show two endothermic effects at $110^{\circ} \mathrm{C}$ and $205^{\circ} \mathrm{C}$ which are characteristic of $\mathrm{Mg}$-vermiculites. Weight loss on the TG curve associated with the endothermic effect at $575^{\circ} \mathrm{C}$ may be attributed to dehydroxylation of partially altered mica comprising this interstratification $[27,28]$.

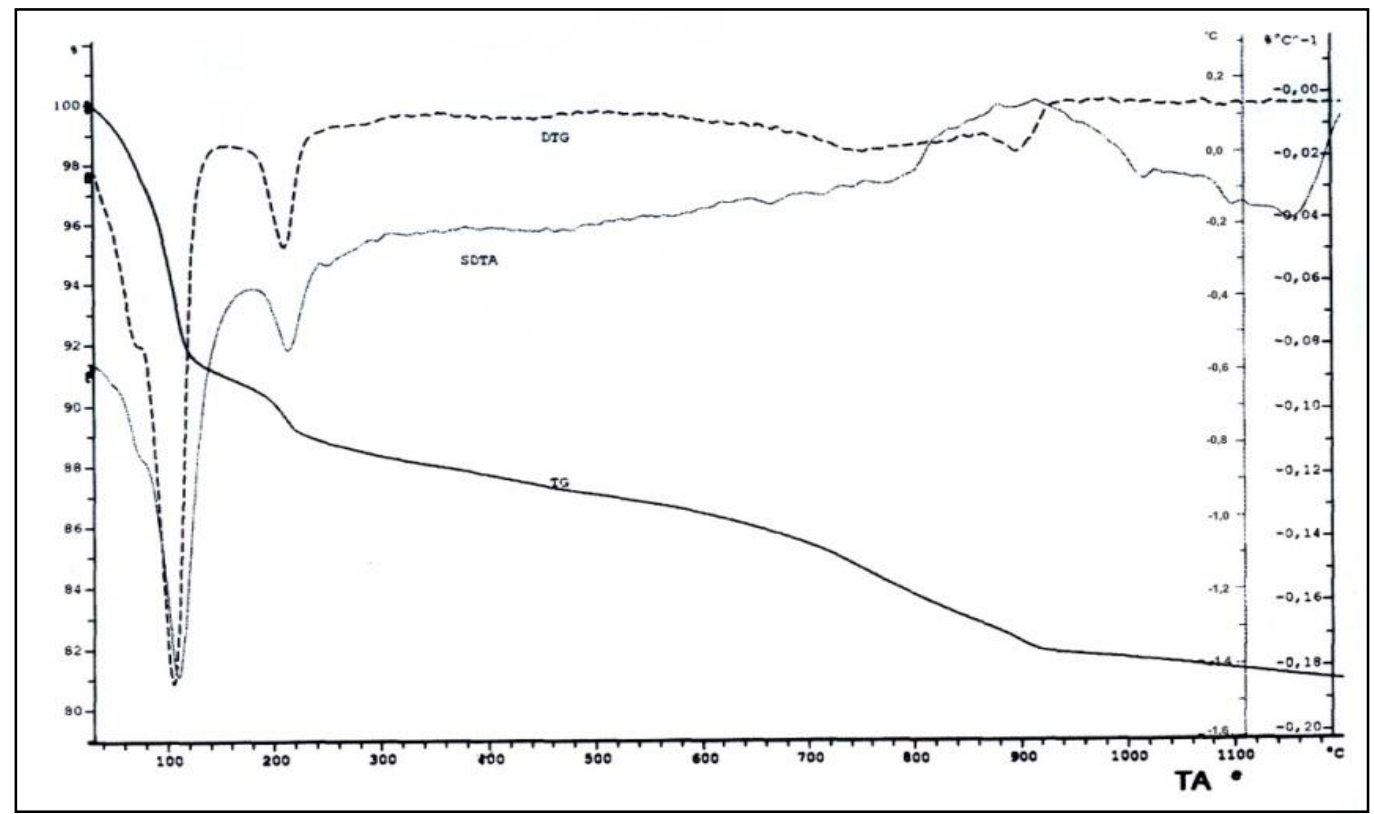

Figure 10. TG/DTA curves for vermiculite.

\subsection{Capacity measurements}

Ion exchange capacity is one of the most important parameters of natural silicate minerals and is connected to the level of undergoing ion exchange. It can be measured as the sum of the exchangeable cations that can be bonded by the mineral framework, and is expressed in meq/g [12]. Isomorphous substitutions of $\mathrm{Al}$ to $\mathrm{Si}$ in the tetrahedral framework and the open tectosilicate structure is the cause of ion exchange capacity. In Table 2, the measured mineral capacities of the studied minerals are given. According to the mineral supplier, the mean value of CEC is 
equal to $1.88 \mathrm{meq} / \mathrm{g}$ for clinoptilolite and $1 \mathrm{meq} / \mathrm{g}$ for bentonite. Kantiranis et al. [29], reported that bentonite deposits in Greece have a capacity between $0.97-1.12 \mathrm{meq} / \mathrm{g}$, with a mean value of $1.04 \mathrm{meq} / \mathrm{g}$ for bentonite deposits of Milos and 0.90-1.30 meq/g for bentonite deposits from Milos Aggeria [29].

TEC is the total sum of the mineral exchangeable cations. The combined concentration of exchangeable cation oxides $\left(\mathrm{MgO}+\mathrm{CaO}+\mathrm{Na}_{2} \mathrm{O}+\mathrm{K}_{2} \mathrm{O}\right)$ for the examined samples is: $7.4 \%$ wt. for clinoptilolite, $11.3 \%$ wt. for bentonite, and $22.5 \% \mathrm{wt}$. for vermiculite. It has to be noted though, that there is a great difference between the structure of zeolites (tectosilicates) and smectite and vermiculite (2:1 phyllosilicates). Mg is mainly a structural cation, i.e. not exchangeable cation, in both smectite (montmorillonite) and vermiculite. So the exchange capacity of those to has to be greater than the sum of $\left(\mathrm{CaO}+\mathrm{Na}_{2} \mathrm{O}+\mathrm{K}_{2} \mathrm{O}\right)$, which in the present case is 2.561 for montmorillonite and 0.281 for vermiculite.

In several literature sources it is stated that the capacity of the two investigated clays is similar, in reality there is some differentiation, mainly attributed to the value of the oxides of bivalent cations $(\mathrm{Ca} / \mathrm{Mg})$ and to the different places that the cations are placed into the crystal structure of the two minerals. Bentonite has a ratio of $\mathrm{Ca} / \mathrm{Mg}$ equal to 0.74 , whereas in vermiculite the same ratio is equal to 0.019. It is noted that bentonite presents elevated concentrations of $\mathrm{Na}_{2} \mathrm{O}$ and $\mathrm{K}_{2} \mathrm{O}$ compared to vermiculite. Calcium ions in bentonites (montmorillonite) are usually hydrated and weakly bound into the structure of the mineral, which makes them easily replaceable by other cations. Further, $\mathrm{Mg}$ in clay minerals is more difficult to exchange compared to calcium, and this makes clays with high $\mathrm{Ca}$ concentration to present higher ion exchange capacities than those who are rich in magnesium ions [29].

Table 2. Mineral ion exchange capacities.

\begin{tabular}{|c|c|c|c|}
\hline Capacity (meq/g) & Clinoptilolite & Bentonite & Vermiculite \\
\hline TEC & $<2.266$ & $<4.312$ & $<11.00$ \\
\hline \multicolumn{4}{|c|}{ MEL } \\
\hline $\mathrm{Pb}$ & $1.668 \pm 0.122$ & $2.667 \pm 0.310$ & $1.974 \pm 0.341$ \\
\hline $\mathrm{Cu}$ & $0.856 \pm 0.144$ & $2.600 \pm 0.491$ & $1.699 \pm 0.079$ \\
\hline $\mathrm{Zn}$ & $0.821 \pm 0.244$ & $2.607 \pm 0.083$ & $1.335 \pm 0.113$ \\
\hline $\mathrm{Mn}$ & $0.575 \pm 0.019$ & $2.336 \pm 1.065$ & $1.246 \pm 0.032$ \\
\hline $\mathrm{Cr}$ & $0.829 \pm 0.124$ & $3.398 \pm 0.585$ & $2.019 \pm 0.280$ \\
\hline
\end{tabular}

\subsection{Porosimetric and microstructural investigations}

Natural zeolites are characterized by primary and secondary porosity. The primary porosity (microporosity $<20 \AA$ or $<2 \mathrm{~nm}$ ) results from the specific crystalline structure of the zeolite particles, which in turn depends upon its composition. Matrix inserted between zeolite particles causes secondary porosity, i.e. the presence of transitional

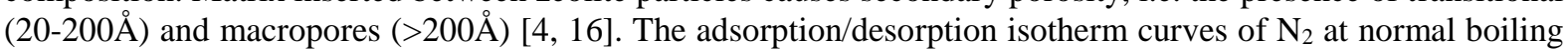
temperature are used for the understanding of the textural properties of porous materials [4]. As it has been mentioned, the heterogeneity parameter $(n)$ shows a dependence on the microporous structure of solids and in particular on the breadth of the pore distribution; the more homogeneous the pores are (decreased breadth), the greater its value. Porosimetric measurements can be used to obtain this type of information; Figs. 11.a-c and Table 3 show the $\mathrm{N}_{2}$ porosimetry results for the tested minerals [30]. Upon observing Figs. 11.a-c, it becomes evident that the discussed minerals refer to Type IV isotherms. This type of isotherm exhibits a hysteresis loop, which is associated with capillary condensation taking place in mesopores, and has a limited uptake over a range of high $\mathrm{P} / \mathrm{P}_{0}$. The initial part of Type IV isotherm is attributed to a monolayer-multilayer adsorption, since it follows the same path as the corresponding part of a Type II isotherm obtained with the given adsorptive on the same surface area of the adsorbent in a non-porous form. Type IV isotherms are characteristic of many mesoporous industrial adsorbents [30].

Table 3. $\mathrm{N}_{2}$ porosimetry analysis results.

\begin{tabular}{lllll}
\hline & Clinoptilolite & Bentonite & Vermiculite \\
\hline BET & BET Area $\left[\mathrm{S}_{\mathrm{BET}}\left(\mathrm{m}^{2} / \mathrm{g}\right)\right]$ & 28.64 & 41.87 & 20.82 \\
& BET C & 375.675 & 583.216 & 216.720 \\
& Vm & 6.574 & 9.613 & 4.779 \\
\hline \multirow{2}{*}{ Langmuir } & Area $\left(\mathrm{m}^{2} / \mathrm{g}\right)$ & 28.18 & 38.12 & 23.44 \\
& Micropore Volume $(\mathrm{ml})$ & 0.01 & 0.014 & 0.0083 \\
& Microporosity & 0.023 & 0.030 & 0.019 \\
& TPV (ml) & 0.085 & 0.087 & 0.028 \\
& Porosity $(\%)$ & 16.3 & 16.7 & 6.1 \\
\hline
\end{tabular}




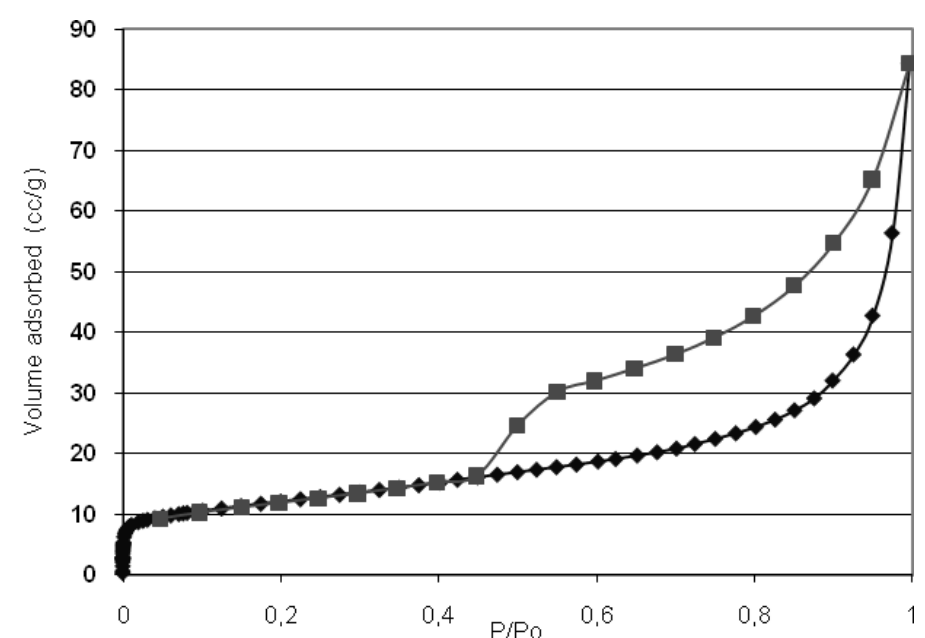

Figure 11a: Sorption-Desorption isotherm curves of bentonite.

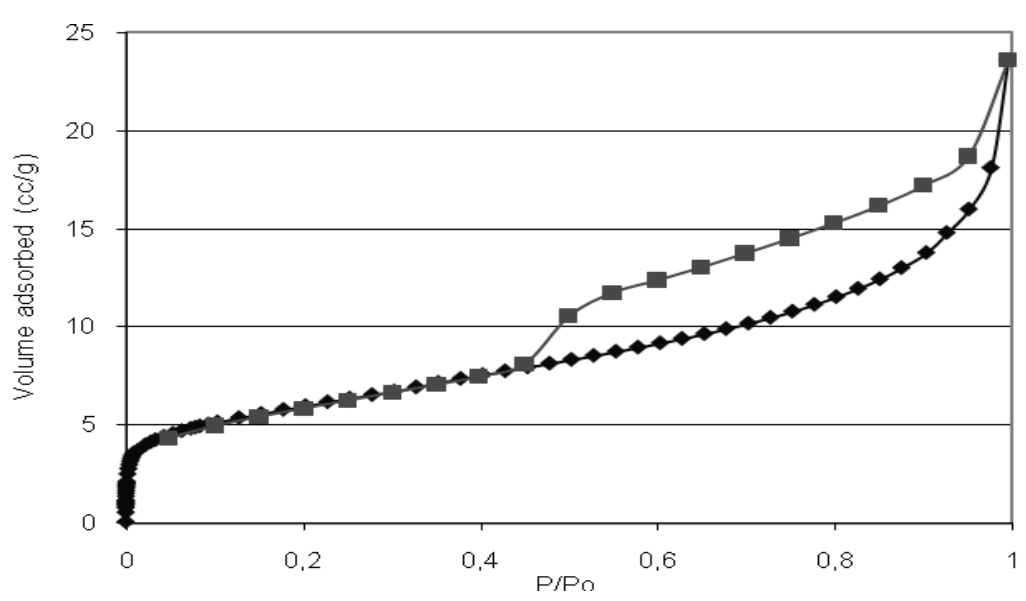

Figure 11c: Sorption-Desorption isotherm curves of vermiculite.

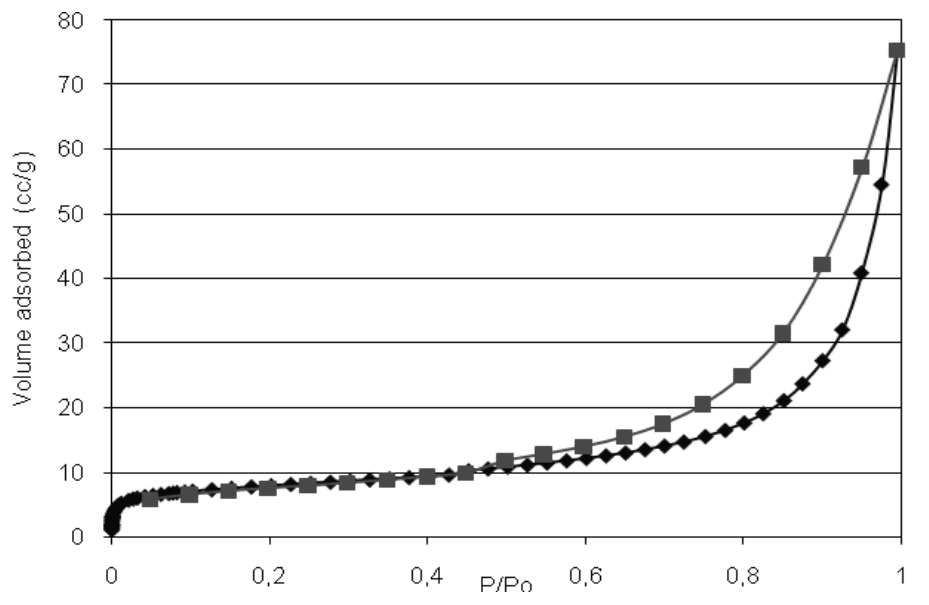

Figure 11b: Sorption-Desorption isotherm curves of clinoptilolite.

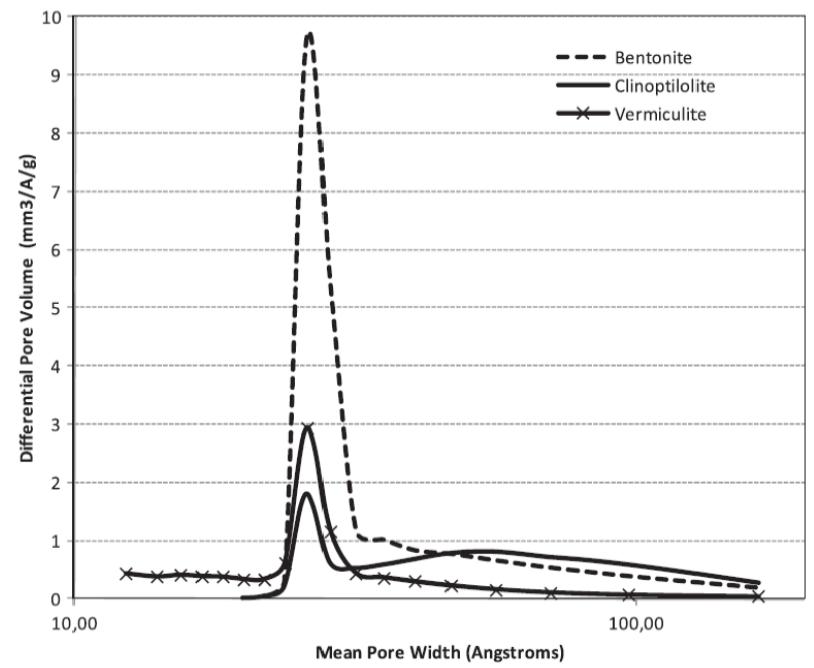

Figure 12. Pore size distribution graph 


\section{Conclusions}

The experimental results of three common natural silicate minerals -one zeolite (clinoptilolite) and two clays (bentonite and vermiculite)- are presented. The methods used are XRD, XRF, FTIR spectroscopy, TG/DTG/DTA, $\mathrm{N}_{2}$-porosimetry (BET). Concerning XRD, the most intense reflection in clinoptilolite corresponds to the d-spacing at the asymmetric position 3.97-3.98 ̊̊ plane, typical of most minerals of this type. Bentonite is mostly composed of montmorillonite, which has its characteristic features at $\mathrm{d}(001)=14.29 \mathrm{~A}^{\circ}$ and $\mathrm{d}(020)=4.49 \mathrm{~A}^{\circ}$. The XRD pattern of natural vermiculite shows the reflection peaks at about $2 \theta: 6^{\circ}, 24^{\circ}$ and $31^{\circ}$, which correspond to the spacing $\mathrm{d}(002)=1.43, \mathrm{~d}(008)=0.48$ and $\mathrm{d}(010)=0.288$, respectively. FTIR analyses show that clinoptilolite exhibits characteristic water bands centered at 3444 and $16737 \mathrm{~cm}^{-1}$. The asymmetric stretching vibration of T-O bonds in the tetrahedral sites corresponds to the band at $1067 \mathrm{~cm}^{-1}$. In bentonite, the absorption peaks group lies between 3620 and $3404 \mathrm{~cm}^{-1}$, which is due to $\mathrm{Al}(\mathrm{Mg})-\mathrm{O}-\mathrm{H}$ stretching and stretching vibration bands $(-\mathrm{OH})$ of water respectively. The other peak bands at $460 \mathrm{~cm}^{-1}$ and $1031 \mathrm{~cm}^{-1}$ were attributed to $\mathrm{Si}-\mathrm{O}-\mathrm{Si}$ and $\mathrm{Si}-\mathrm{O}$ bending vibrations, respectively. In vermiculite, the main absorption band appears at $3387 \mathrm{~cm}^{-1}$, which is characteristic of the stretching vibrations of the surface structural hydroxyl groups, whereas the bands around $996-957 \mathrm{~cm}^{-1}$ correspond to $\mathrm{Si}-\mathrm{O}-\mathrm{Si}$ stretching vibrations. $\mathrm{XRF}$ chemical analysis demonstrates that clinoptilolite $\mathrm{Si} / \mathrm{Al}$ ratio is always higher than 4 , while exchangeable cation oxides $\left(\mathrm{MgO}+\mathrm{CaO}+\mathrm{Na}_{2} \mathrm{O}+\mathrm{K}_{2} \mathrm{O}\right)$ generally varies from 6-13 $\mathrm{wt} \%$. In bentonite and vermiculite, $\mathrm{Si} / \mathrm{Al}$ ratio is normally less than 4 , which is typical for heulandites as well. Typical characteristics of vermiculite include $\mathrm{K}_{2} \mathrm{O}$ content ranging from 0-3 wt. \% and high $\mathrm{Mg}$ concentrations (>15 wt. \%). Thermogravimetric analysis, show that the main regions of clinoptilolite weight loss are the release of loosely-bound water $\left(50-200^{\circ} \mathrm{C}\right)$, release of "zeolitic" water $\left(200-700^{\circ} \mathrm{C}\right)$ and finally collapse of crystal structure $\left(700-900^{\circ} \mathrm{C}\right)$. In the case of bentonite, the adsorbed water is typically released at about $130^{\circ} \mathrm{C}$, while weight loss at $525^{\circ} \mathrm{C}$ and between $600-1200^{\circ} \mathrm{C}$ are attributed to surface dehydroxylation, resulting in two endothermic peaks of absorbed water and crystalinity water losses. Dehydration of natural vermiculite occurs in two steps in the range of $30-300^{\circ} \mathrm{C}$; the first step (up to $125^{\circ} \mathrm{C}$ ) refers to the release of physically adsorbed water molecules, that are not in the contact with sample ions, while the second step (up to $200-250^{\circ} \mathrm{C}$ ) refers to the release of water molecules intermediately contacting mineral ions. As far as porosity is concerned, all three minerals are generally dominated by micro/mesopores. BET surface area for clinoptilolite is between $17-100 \mathrm{~m}^{2} / \mathrm{g}$, for bentonite $22-42 \mathrm{~m}^{2} / \mathrm{g}$ and for vermiculite $7-18 \mathrm{~m}^{2} / \mathrm{g}$. The above analytical results enabled the full characterization of the examined minerals, despite their common properties.

\section{$5 \quad$ References}

1. Querol, X., et al., Synthesis of zeolites from fly ash at pilot plant scale. Examples of potential applications. Fuel 2001.80 p. 857-865.

2. Juan, R., et al., Ion exchange uptake of ammonium in wastewater from a Sewage Treatment Plant by zeolitic materials from fly ash. Journal of Hazardous Materials, 2009. 161 p. 781-786.

3. Olivares-Marín, M., T.C. Drage, and M.M. Maroto-Valer, Novel lithium-based sorbents from fly ashes for CO2 capture at high temperatures. International Journal of Greenhouse Gas Control, 2010. 4: p. 623629.

4. $\quad$ Inglezakis, V.J. and A. Zorpas, Natural Zeolites Handbook2012: Bentham Science Publishers.

5. Mamba, B.B., et al., Metal adsorption capabilities of clinoptilolite and selected strains of bacteria from mine water. Physics and Chemistry of the Earth, Parts A/B/C, 2009. 34 p. 830-840.

6. Pelot, D.D., S. Jun, and A.L. Yarin, Bentonite Dispersions: Transition from Liquid-like to Solid-like Behavior and Cracking. Journal of Non-Newtonian Fluid Mechanics, 2015. 219 p. 50-64.

7. Valášková, M. and G.S. Martynková, Vermiculite: Structural Properties and Examples of the Use, in Clay Minerals in Nature - Their Characterization, Modification and Application, M. Valášková and G.S. Martynková, Editors. 2012, E-Publishing Inc., InTech. p. 209-238.

8. Inglezakis, V.J., The concept of "capacity" in zeolite ion-exchange systems. Journal of Colloid and Interface Science, 2005. 281(1): p. 68-79.

9. Inglezakis, V.J. and S.G. Poulopoulos, Adsorption, Ion Exchange and Catalysis: Design of Operations and Environmental Applications2006, Netherlands: Elsevier.

10. Brunauer, S., P.H. Emmett, and E. Teller, Adsorption of Gases in Multimolecular Layers. Journal of the American Chemical Society, 1938. 60 (2): p. 309-319.

11. Ruthven, M.D., Principles of Adsorption and Adsorption Process 1984, New York: Wiley \& Sons.

12. Perraki, T. and A. Orfanoudaki, Mineralogical study of zeolites from Pentalofos area, Thrace, Greece. Applied Clay Science, 2004. 25 p. 9 - 16.

13. Perraki, T. and A. Orfanoudaki, Mineralogical composition and physical properties of bentonites of the island of Milos. Mineral Wealth, 1997. 104 p. 35-42.

14. Grim, R.E., Clay Mineralogy1953, New-York: McGraw-Hill. 
15. Nayak, P.S. and B.K. Singh, Instrumental characterization of clay by XRF, XRD and FTIR. Bulletin of Materials Science, 2007. 30 (3): p. 235-238.

16. Tsitsishvili, G.V., et al., Natural Zeolites, ed. E. Horwood1992, Chichester, UK.

17. Perraki, T., G. Kakali, and F. Kontoleon, The effect of natural zeolites on the early hydration of Portland cement. Microporous and Mesoporous Materials, 2003. 61 p. 205-212.

18. Mumpton, F., Clinoptilolite Redefined. The American Mineralogist, 1960. 45 p. 351-369.

19. Elaiopoulos, K., T. Perraki, and E. Grigoropoulou, Mineralogical study and porosimetry measurements of zeolites from Scaloma area, Thrace, Greece. Microporous and Mesoporous Materials, 2008. 112 (13): p. 441-449.

20. Perez-Maqueda, L.A., et al., Study of natural and ion exchanged vermiculite by emanation thermal analysis, TG, DTA and XRD. Journal of Thermal Analysis and Calorimetry 2003. 71 p. 715-726.

21. Cruciani, G., Zeolites upon heating: Factors governing their thermal stability and structural changes. Journal of Physics and Chemistry of Solids, 2006. 67 p. 1973-1994.

22. Tomazovic, B., T. Ceranic, and G. Sijaric, The properties of the NH4-clinoptilolite. Part 1. Zeolites, 1996. 16 (4): p. 301-308.

23. Doula, M.K., Synthesis of a clinoptilolite-Fe system with high Cu sorption capacity. Chemosphere, 2007. 67 p. 731-740.

24. Sarikaya, Y., et al., The Effect of Thermal Treatment on Some of the Physicochemical Properties of a Bentonite. Clays and Clay Minerals, 2000. 48 (5): p. 557-562.

25. Tabak, A., et al., Characterization and pillaring of a Turkish bentonite (Resadiye). Journal of Colloid and Interface Science, 2007. 313 p. 5-11.

26. Caglar, B., et al., Characterization of the cation-exchanged bentonites by XRPD, ATR, DTA/TG analyses and BET measurement. Chemical Engineering Journal, 2009. 149 p. 242-248.

27. Ruiz-Conde, A., et al., Interaction of vermiculite with aliphatic amides (Formamide, acetamide and propoinamide): formation and study of interstratified phases in the transformation of Mg- to NH4Vermiculite. Clays and Clay Minerals, 1997. 45 (3): p. 311-326.

28. Justo, A., J.L. Perez-Rodríguez, and P.J. Sanchez-Soto, Thermal study of vermiculites and micavermiculite interstratifications. Journal of Thermal Analysis, 1993. 40 p. 59-65.

29. Kantiranis, N., et al., Study of binding capacity of Milos bentonite and attapulgite of Grevena, in $2 n d$ Conference of the Economic geology, mineralogy and geochemistry2005: Thessaloniki. p. 105-112.

30. Inglezakis, V.J., M. Stylianou, and M. Loizidou, Ion exchange and adsorption equilibrium studies on clinoptilolite, bentonite and vermiculite. Journal of Physics and Chemistry of Solids, 2010. 71(3): p. 279284. 